УДК 373.2.015.3:159.922.7

https://doi.org/10.52058/2786-4952-2022-1(6)-173-183

Іваненко Наталія Вольдемарівна аспірант кафедри дошкільної освіти, Київський університет імені Бориса Грінченка, вул. Бульварно-Кудрявська,18/2, м. Київ, 04053, тел.: (044) 272-19-02, https://orcid.org/0000-0002-5238-0768

Козак Людмила Василівна доктор педагогічних наук, доцент, професор кафедри дошкільної освіти, Київський університет імені Бориса Грінченка, вул. Бульварно-Кудрявська, 18/2, м. Київ, 04053, тел.: (044) 272-19-02, https://orcid.org/0000-0002-4528-1905

\title{
ПЕДАГОГІЧНИЙ СУПРОВІД ДІТЕЙ ДОШКІЛЬНОГО ВІКУ ЯК ПСИХОЛОГО-ПЕДАГОГІЧНА ПРОБЛЕМА
}

Анотація. У статті висвітлено актуальні питання педагогічного супроводу дітей дошкільного віку. Встановлено, що звернення багатьох сучасних учених до феномену педагогічного супроводу не $є$ випадковим. У педагогіку це поняття увійшло за поняттями психологічна й соціальна допомога та підтримка, що обумовлено проникненням до освітнього простору ідей гуманістичної філософії та психології: розуміння людини як творця власного життя; здатність людини до саморозвитку та особистісного зростання, реалізації внутрішнього потенціалу; унікальність кожної людини. Надзвичайно важливим чинником має стати організація педагогічного супроводу дитини дошкільного віку, тобто ставлення до неї не лише як до об'єкта засвоєння знань та умінь, а й як до суб'єкта спілкування, співпраці, розширення ступенів іï свободи, надання права на власний вибір. Проаналізовано поняття психологічний супровід, психолого-педагогічний та педагогічний супровід, соціально-педагогічний супровід. Педагогічний супровід розглядають як технологію взаємодії між учасниками освітнього процесу (педагогами, дітьми, батьками), яка спирається на сильні сторони дитини, іiі особистісний потенціал, свободу і самостійність, метою якої $€$ позитивна динаміка в розвитку кожної дитини, що дозволяє сформувати у неї здібності до саморегуляції, адаптивності в реальних ситуаціях життєдіяльності. У теорії супроводу важливим положенням виступає твердження, що носієм проблеми розвитку дитини у кожному конкретному випадку виступає і сама дитина, і іiі батьки, і найближче оточення дитини, i педагоги. Зроблено висновок, що модель педагогічного супроводу засновується на компетентнісному підході та реалізується на основі взаємодії його основних складових компонентів: цілепокладання, стратегії планування змісту та технології його реалізації, чіткого визначення рольових позицій усіх учасників освітнього процесу, єдності принципів та очікуваних 
Журнал«Герстективита інновації наукиљ

(Серія«Гедагогіка», Серія«Гцихологія», Серія«Медицинв»

№(6) 2022

результатів; створення оптимальних умов для особистісного розвитку дитини.

Ключові слова: дошкільний вік, супровід, психологічний супровід, психолого-педагогічний супровід, педагогічний супровід, соціальнопедагогічний супровід.

Ivanenko Natalia Voldemarivna Graduate student of the Department of Preschool Education, Borys Grinchenko Kyiv University, Bulvarno-Kudryavska St., 18/2, Kyiv, 04053, tel.: (044) 272-19-02, https://orcid.org/0000-0002-5238-0768

Kozak Liudmyla Vasylivna Doctor of Pedagogical Sciences, Docent, Professor of the Preschool Education Department, Borys Grinchenko Kyiv University, Bulvarno-Kudryavska St., 18/2, Kyiv, 04053, tel.: (044) 272-19-02, https://orcid.org/ 0000-0002-4528-1905

\section{PEDAGOGICAL SUPPORT OF CHILDREN OF PRESCHOOL AGE AS A PSYCHOLOGICAL AND PEDAGOGICAL PROBLEM}

Abstract. The article highlights current issues of pedagogical support of preschool children. It was found that the appeal of many modern scientists to the phenomenon of pedagogical support is not accidental. In the pedagogy, this concept was included after the concepts of psychological and social assistance and support, due to the penetration into the educational space of the ideas of humanistic philosophy and psychology: understanding of man as the creator of his own life; human ability to self-development and personal growth, realization of inner potential; the uniqueness of each person. An extremely important factor should be the organization of pedagogical support of preschool children, ie attitude to it not only as an object of acquisition of knowledge and skills, but also as a subject of communication, cooperation, expanding its freedom, giving the right to choose. It was analyzed the concepts of psychological support, psychological-pedagogical and pedagogical support, social-pedagogical support. Pedagogical support is considered as: technology of interaction between participants in the educational process (teachers, children, parents), which is based on the strengths of the child, his personal potential, freedom and independence, which aims at positive dynamics in the development of each child, which allows it to form the ability to self-regulation, adaptability in real life situations. In the theory of support, an important provision is the statement that the carrier of the problem of child development in each case is the child himself, and his parents, and the child's immediate environment, and teachers. The model of pedagogical support is based on the competence approach and is implemented on the basis of interaction of its main components: goal setting, content planning strategy and technology of its implementation, clear definition of role positions of all participants in the educational process, unity of principles and expected results; creating optimal conditions for the personal development of the 
child.

Keywords: preschool age, support, psychological support, psychological and pedagogical support, pedagogical support, socio-pedagogical support.

Постановка проблеми. Найпершим суспільним середовищем для дитини є дошкільний заклад, головне призначення якого - соціальна адаптація до умов життя в товаристві незнайомих дітей і дорослих, виховання ціннісного ставлення до природи, людей, самої себе. Саме заклад дошкільної освіти має забезпечити фізичне, психічне здоров'я дитини, іiі різнобічний гармонійний розвиток, набуття життєвого досвіду, стати своєрідним посередником між сім'єю та широким світом.

У вирішенні цих завдань надзвичайно важливим чинником має стати організація педагогічного супроводу дитини дошкільного віку, тобто ставлення до неї не лише як до об’єкта засвоєння знань та умінь, а й як до суб'єкта спілкування, співпраці, спільної діяльності, розширення ступенів іiі свободи, надання права на власний вибір. Знання, вміння та навички визнаються психологами та педагогами не лише як показники розвитку особистості, а й як вихідні якості особистісного зростання. Вікові та індивідуальні особливості розглядаються як ступені реалізації свого природного потенціалу, зокрема, соціального, пізнавального, художнього, творчого, інтелектуального.

Потреби часу передбачають, щоб зміни у ставленні дитини до власного «Я» були позитивними. А для цього педагогам потрібно допомогти дитині пізнати себе, інших людей; навчити іiі відчувати власний стан, аналізувати поведінку, адекватно оцінювати реальні успіхи, запобігати невдачам [1].

На думку Т. Сєдової, найкращою системою роботи з дітьми є така, у якій виявляється і розвивається кожна дитина, виявляються іiі нахили і здібності. Система має бути спрямована, перш за все, на те, щоб пізнати талант кожного і розвинути його. Одним із напрямів цієї роботи є педагогічний супровід система підтримки та допомоги дитині у навчально-виховному процесі [2].

Аналіз останніх досліджень і публікацій. Звертання багатьох сучасних вчених до проблеми обгрунтування парадигми педагогічного супроводу (М. Бившева, М. Іваненко, I. Ісаєва, І. Кареліна, К. Крутій, І. Рогальська, О. Трофімова та ін.) не є випадковим. У педагогіку це поняття увійшло за поняттями психологічна й соціальна допомога та підтримка, що обумовлено проникненням до освітнього простору ідей гуманістичної філософії та психології: розуміння людини як творця власного життя; здатність людини до саморозвитку та особистісного зростання, реалізації внутрішнього потенціалу; унікальність кожної людини (дитини).

Парадигма педагогічного супроводу дітей дошкільного віку своєю появою у педагогічній теорії та практиці багато в чому завдячує утвердженню особистісно-орієнтованої моделі освіти. Обистісноорієнтований підхід в освіті розглядається сучасними вченими як важливий 
психолого-педагогічний принцип, як методологічний інструментарій, основу якого становить сукупність вихідних концептуальних уявлень, цільових установок, методико-психодіагностичних та психолого-технологічних засобів, які забезпечують більш глибоке цілісне розуміння, пізнання особистості дитини, і на цій основі - ऑï гармонійний розвиток в умовах функціонування системи освіти.

Особистісно-орієнтована освіта - це освіта, що гармонійно резонує 3 внутрішнім світом дитини. Вона ставить перед вихователем такі завдання: забезпечити особистісний розвиток суб'єктності дитини, і1і інтелектуальний, духовно-моральний, фізичний розвиток, формування в іiі світогляді цілісної картини світу. Центральним моментом педагогічного керівництва при такому підході більшість вчених (І. Бех, С. Бондаревська, В. Слободчиков та ін.) вважають допомогу, підтримку, соціально-педагогічний захист. Таким чином, проблема створення умов для цілісного, гармонійного розвитку дитини дошкільного віку в освітньому процесі $є$ одним із пріоритетних напрямів діяльності закладу дошкільної освіти.

Мета статті - дослідження сутності та особливостей педагогічного супроводу дітей дошкільного віку як психолого-педагогічної проблеми.

Виклад основного матеріалу. Поняття «педагогічна підтримка», яке міцно закріпилося у вітчизняній освіті, стало вихідним для появи нового терміну - «педагогічний супровід», який найбільш повно відповідає гуманістичним підходам до взаємодії в освітньому процесі відповідно до соціокультурної ситуації, що постійно змінюється (І. Бех, К. Роджерс та ін.).

Розглянемо детальніше сутність поняття «супровід». Тлумачний словник української мови подає таке пояснення супроводу: «Супровід - те, що супроводить яку-небудь дію, явище, товариство, оточення; група людей, яка супроводжує когось» [3]. С. Гончаренко відмічає багатоаспектність поняття «супровід», розрізняючи його як: дію зі значенням супроводжувати, супроводити; те, що супроводить якусь дію, явище; поєднання дії 3 іншою, побічною дією; додавання чогось до чогось, доповнення до чогось [4]. Е. Козакова подає таке тлумачення супроводу: «Супровід - це метод, який забезпечує створення умов для прийняття суб'єктом розвитку оптимальних рішень у різних ситуаціях життєвого вибору» [5]. І. Рогальська наголошує на одній принциповій особливості супроводу: одночасне знаходження поруч, як посередництво між соціальним світом і власним життєвим світом дитини, забезпечення іiі захисту, позитивного самопочуття, підтримки в небезпечних ситуаціях [6].

Як свідчить аналіз підходів до обгрунтування змістового навантаження поняття «супровід», його іноді вважають однією 3 моделей, яка відрізняється від інших самостійних моделей - моделі підтримки, моделі корекції тощо. Супровід також визначають як цілеспрямовану діяльність, яка супроводжує весь процес життєдіяльності дітей і педагогів закладу дошкільної освіти [7, с. 22]. 
Зазначимо, що модель супроводу, зміст якого має свою специфіку, знайшла спочатку широке розповсюдження у психології. Проте у сучасній психології ще не маємо єдиного методологічного підходу до визначення сутності психологічного супроводу. Його характеризують як усю систему професійної діяльності психолога (М. Бітянова), як загальний метод роботи психолога (Н. Глуханюк), як один 3 напрямів та технологій професійної діяльності психолога (Р. Овчарова). Сутнісною характеристикою супроводу у психологічному контексті $\epsilon$ створення соціально-психологічних умов для емоційного благополуччя, успішного розвитку, виховання та навчання дітей в ситуаціях соціально-педагогічної взаємодії, яка організується в межах освітнього закладу.

У психолого-педагогічній літературі (І. Бех, О. Газман, О. Запорожець, Н. Кудикіна, Н. Михайлова, Г. Строєва, О. Лідерс) прослідковується інтерес до феномену психолого-педагогічного супроводу, який сприяє особистісному розвитку і вихованню дитини. На думку дослідників, основи такого супроводу не протирічать ідеям особистісно зорієнтованого підходу, співзвучні з ними, та водночас розвивають та культивують суб'єктний потенціал дитини.

Психолого-педагогічний супровід досі не має завершеного цілісного наукового опису, в ньому спостерігаються ознаки, які відносяться до різних галузей наукового знання: педагогіки, соціальної педагогіки, психології, соціології. Широка інтерпретація педагогічного змісту супроводу пов’язується зі створенням сприятливих умов, безпечного середовища, необхідних для розвитку i саморозвитку дитини, розкриттям, реалізацією внутрішнього потенціалу, формуванням здатності до самостійних дій та вільного вибору. У працях І. Беха, О. Газмана, Н. Кудикіної супровід розглядається як цілісний процес створення необхідних соціальних та психолого-педагогічних умов для успішного гармонійного розвитку кожної дитини. Завдання педагогічного супроводу - створювати умови для успішного і продуктивного руху дитини іiі життєвим шляхом, допомога їй в усвідомленні свого «Я», розумінні себе й інших, засвоєнні взаємовідносин з однолітками, іншими дітьми, дорослими.

M. Бардієр, I. Ромазан i T. Чередникова вважають, що особливість психолого-педагогічного супроводу полягає у цінності самостійного вибору дитиною свого життєвого шляху. Дорослий повинен цінувати природні механізми розвитку дитини, не руйнувати їх, а розкривати, при цьому самому бути і спостерігачем, і співучасником, і дослідником. На їх думку, завдання дорослих - сформувати здатність і готовність вихованця до усвідомлення своїх можливостей і потреб, здійснення самостійного вибору. Педагогу потрібно не перебирати ці вибори на себе, а навчити дитину ставити та досягати індивідуальних цілей, співвідносячи їх iз цілями оточуючих людей i суспільними цінностями. На думку цих дослідників, супровід здійснюється в різних за формами психологічних розвивальних заняттях [8].

Зазначимо, що психолого-педагогічний супровід сьогодні $\epsilon$ не просто сукупністю різноманітних методів коректувально-розвивальної роботи 3 
Журнал«Герспективитаіновації наукиљ

(Серія«Гедагогіка», Серія«ГЕихологія», Серія«Медицина»

№1(6) 2022

дітьми, а виступає комплексною технологією, особливою культурою підтримки і допомоги дитині у вирішенні завдань іiі розвитку, навчання, виховання, соціалізації. Відтак, фахівець з психолого-педагогічного супроводу повинен не лише володіти методиками діагностики, консультування, корекції, але й мати навички системного аналізу проблемних ситуацій, програмування i планування діяльності, спрямованої на їх вирішення, співорганізацію з цією метою учасників освітнього процесу (дитина, однолітки, батьки, педагоги, адміністрація) [9].

Узагальнюючи наведені вище підходи, можна дійти висновку, що загальною метою психолого-педагогічного супроводу дитини в навчальновиховному процесі $є$ забезпечення всебічного розвитку дитини. Для цього необхідно: 1. Забезпечити умови для самореалізації особистості, використовуючи сучасні технології навчання. 2. Скорегувати програми, які задовольняють пізнавальні потреби різного рівня через систему основного й додаткового навчання (інваріантна частина освітніх програм, додаткові години). 3. Спрямувати роботу з батьками на виявлення та розвиток здібностей їхньої дитини. 4. Скоординувати роботу фахівців 3 даної проблеми щодо надання кожній дитині індивідуальних рекомендацій щодо створення карт просування здібних дітей [там само].

До проблеми обгрунтування парадигми педагогічного супроводу зверталися вітчизняні і зарубіжні вчені. Так, на думку Є. Казакової, педагогічний супровід - це метод, що забезпечує створення умов прийняття суб'єктом оптимальних рішень у різних ситуаціях життєвого вибору. При цьому суб'єкт визначається і як людина, що розвивається, і як система, котра розвивається [10]. За М. Шакуровою, педагогічний супровід $є$ одним із «механізмів тривалої двосторонньої педагогічної взаємодії». Автором висвітлено такі характеристики, що належать цій взаємодії: суб'єктна позиція всіх учасників процесу; спільність і взаємореферентність, яка приймається та підтримується суб'єктами взаємодії; багатопроєктність; схожість інтерпретацій; адаптивність; переважне використання «м'яких» методів педагогічної взаємодії [11]. М. Іваненко визначає педагогічний супровід як технологію взаємодії між учасниками освітнього процесу (педагогами, дітьми, батьками), яка спирається на сильні сторони дитини, іiі особистісний потенціал, свободу і самостійність, має за мету позитивну динаміку в розвитку кожної дитини і дозволяє сформувати у неї здібності до саморегуляції, адаптивності в реальних ситуаціях життєдіяльності [12, с. 9]. Дослідниця стверджує, що до таких понять, як підтримка, допомога, забезпечення поняття супроводу не зводиться, за обсягом воно є більшим. Його основу становить збереження максимуму свободи та відповідальності суб'єкта розвитку за вибір варіанту розв’язання проблеми.

Вітчизняна дослідниця К. Крутій під супроводом розуміє метод, що забезпечує створення умов для вибору суб'єктом оптимальних рішень у різних ситуаціях життєвого вибору. Суб’єктами розвитку є дошкільник i 
соціальна система. «Супровід - це комплексний метод, в основі якого єдність чотирьох функцій: діагностика проблеми, що виникла; інформація про проблему і шляхи іiі рішення; консультація на етапі вибору рішення i вироблення плану рішення проблеми; первинна допомога та етапі реалізації плану рішення» [13]. Дослідниця пояснює, що використання терміну «супровід» продиктовано необхідністю додатково виокремити самостійність суб'єкта у виборі рішення. Слід погодитися 3 тим, що «супроводжувальний розвиток» $\epsilon$ альтернативою розвитку, що направляється, бо основний його постулат - віра у внутрішні сили дитини, потреба в самореалізації. Тобто, основними пріоритетами супроводу мають стати навчання вибору, створення орієнтаційного поля розвитку, зміцнення внутрішнього «Я» дитини дошкільного віку. К. Крутій робить висновок, що в основі психологопедагогічного супроводу повинна лежати теоретична модель, що є єдністю концептуальних положень і технологій, зорієнтована на розв'язання проблем розвитку дитини в різних соціальних системах. Дослідниця наполягає на тому, що в основу проектованої моделі супроводу мають бути покладені такі принципи: гуманізація, системний підхід, комплексний підхід, урахування індивідуальних і вікових особливостей дитини, безперервність. Змістове наповнення психолого-педагогічного супроводу включає такі параметри: попередження виникнення проблем розвитку дитини; допомога дитині у вирішенні актуальних завдань розвитку, навчання i виховання; психологічне забезпечення індивідуальних освітніх програм; розвиток психолого-педагогічної компетентності батьків і педагогів. У реальній практиці, як зазначає дослідниця, подібна модель майже не використовується, а супровід здійснюється фрагментарно та еклектично.

Проблема соціально-педагогічного супроводу дитини розглядається у працях I. Р огальської. Вона зазначає, що соціально-педагогічний супровід молодших школярів забезпечує умови для поетапного якісного соціального зростання дітей, стрижнем якого $є$ морально-ціннісна площина розвитку особистості, оскільки саме вона визначає позицію дитини в світі, систему іiі ставлень до природи, предметної і духовної культури, людей, самої себе [14]. Сутність соціально-педагогічного супроводу полягає у створенні у межах соціального простору дитинства умов для засвоєння дитиною позиції суб'єкта соціалізації і виявлення себе суб'єктом власної життєтворчості. I. Рогальська підкреслює, що принциповою відмінністю соціальнопедагогічного супроводу від інших моделей (підтримки або корекції) є те, що успішність соціалізації особистості досягається за умови створення ефективних умов, пошуку прихованих ресурсів, прищеплення дитині імунітету проти негативних впливів соціального оточення, що дозволить запобігати ¥ї неблагополуччю, сформувати стійкість перед негативними впливами соціального середовища.

Отже, стає зрозумілим, що педагогічний супровід можливо реалізувати, використовуючи декілька видів педагогічного впливу [15]: 
1) супровід-співробітництво педагога й дитини. Суть співробітництва полягає в допомозі дитині усвідомити сутність проблеми, виявити власні реальні та потенційні можливості, обрати найбільш оптимальні варіанти рішень. Супровід-співробітництво передбачає спільне планування педагога й дитини, аналіз, співтворчість, рефлексію, вимагає дій, необхідних для подальшого самостійного подолання проблем, які виникли, тобто прояву особистої відповідальності, творчості, власних унікальних якостей дитини;

2) супровід-ініціювання, відомий 3 часів Сократа, суть якого сформулювала М. Монтессорі: «Допоможи мені це зробити самому, нічого не роблячи за мене, спрямуй у потрібне річище, підштовхни до рішення, а все інше я зроблю сам». Організовуючи супровід-ініціювання, педагог створює дитині необхідні умови для вільного, індивідуального, самостійного вибору шляху та засобів вирішення виховних завдань $\mathrm{i}$, тим самим, допомагає дитині відкрити загальновизнані моральні істини;

3) супровід-попередження. Педагог, випереджаючи небажані події, їх можливий негативний розвиток, передбачає невірні кроки дітей i, тим самим, допомагає обрати адекватні рішення з урахуванням поведінки та діяльності дитини. Логіка дій педагога допоможе дитині розібратися в сутності проблеми, намітити можливі варіанти дій для іiі вирішення, обрати найбільш оптимальний із них, стимулювати виконання прийнятого рішення.

У науковій літературі мають місце різні підходи та критерії до визначення видів (форм) педагогічного супроводу: опіка, наставництво, партнерство, співпраця, співдружність (А. Бєлкін); захист, допомога, підтримка, супровід (М. Бившева, Н. Касіцина, Н. Михайлова, С. Юсфін); добровільна та вимушена форми супроводу, запланований та імпровізаційний супровід, довгостроковий i короткостроковий, «живий» контакт i заочний, продуктивний і непродуктивний (Є. Коротаєва); метод створення сприятливих умов (К. Крутій); комплексний метод, що включає діагностику, інформаційне забезпечення, консультація та первинна допомога (К. Крутій, Н. Рогальська).

Таким чином, педагогічний супровід передбачає: інтелектуальний, соціальний i духовний розвиток особистості дитини 3 урахуванням іiі індивідуальних особливостей, стану здоров'я, потреб суспільства; оптимальну реалізацію цілісного розвивального впливу навчання, виховання та освіти на особистість дитини; максимальну мобілізацію психічних ресурсів особистості, спрямовану на інтенсивний саморозвиток, що водночас забезпечуватиме i повну самореалізацію, творчу налаштованість.

Висновки. Узагальнюючи результати наукових досліджень відзначимо, що підхід до розв'язання проблеми супроводу розглядається як парадигмальний, що підкреслює його діяльнісну та суб'єктну природу, ненасильницький, безперервний та ціннісний характер. У науковому полі існує поліваріантність підходів в обгрунтуванні сутності поняття «супровід» (через видові ознаки (відмінності)): механізм тривалої двосторонньої педагогічної взаємодії; створення умов для прийняття суб'єктом розвитку 
оптимальних рішень у різних ситуаціях життєвого вибору; посередництво між соціальним світом і власним життєвим світом дитини, забезпечення іiі захисту, позитивного самопочуття, підтримки в небезпечних ситуаціях; допомога дитині, iï сім’і та педагогам у формуванні орієнтаційного поля розвитку; метод, що забезпечує єдність всіх суб'єктів освітнього процесу; система професійної діяльності педагога, психолога, що спрямована на створення умов для успішного навчання і розвитку особистості; технологія взаємодії між учасниками освітнього процесу (педагогами, дітьми, батьками), яка спирається на сильні сторони дитини, ії особистісний потенціал, свободу і самостійність; створення оптимальних умов для особистісного розвитку дитини; цілісна система психологічного забезпечення освітнього процесу, в якій взаємодіють діагностичний, розвивальний, профілактичний і соціальний напрями; «ведення» дитини за індивідуальним освітнім маршрутом за умови добору відповідних освітніх програм. Встановлено, що поняття «супровід» $\epsilon$ більш широким за обсягом та динамічним за значенням і змістом. У теорії супроводу важливим положенням виступає твердження, що носієм проблеми розвитку дитини у кожному конкретному випадку виступає і сама дитина, і їі батьки, і найближче оточення дитини, і педагоги.

Поняття «супровід», можемо вважати комплексним методом, в основі якого лежить єдність чотирьох функцій: діагностична (виявлення суті проблеми); інформаційна (розкриття шляхів розв'язання проблеми); консультаційна (надання допомоги на етапі ухвалення рішення й вироблення плану вирішення проблеми); оперативна (вчасна допомога в розв'язанні проблеми 3 опорою на потенційні можливості особистості), аналітична (вивчення результатів педагогічного супроводу, корекція відхилень у розв'язанні проблем, пошук шляхів удосконалення умов для самореалізації суб'єкту супроводу). Модель педагогічного супроводу грунтується на компетентнісному підході та реалізується на основі взаємодії його основних складових компонентів: цілепокладання, стратегії планування змісту та технології його реалізації, чіткого визначення рольових позицій усіх учасників освітнього процесу, єдності принципів та очікуваних результатів.

Виокремлюють психологічний, психолого-педагогічний, педагогічний, соціально-педагогічний супровід залежно від певних проблем, умов, потреб, освітньої мети і завдань, професіоналізму кадрів тощо. В останній час значно активніше використовується поняття «педагогічний супровід» щодо дітей дошкільного віку. Проведене дослідження не вичерпує всіх аспектів зазначеної проблеми. Подальшого дослідження потребує вивчення особливостей педагогічного супроводу пізнавального розвитку дітей шостого року життя.

\section{Лimepamypa:}

1. Гарвасюк I. Г. Психологічний супровід обдарованої дитини // Освіта та розвиток обдарованої особистості. № 3 (22) /03/2014. С. 46-50. 
2. Сєдова Т. Д. Ціннісні орієнтації педагогічного супроводу обдарованих учнів освітньому середовищі гімназії // Організація роботи 3 обдарованими учнями: досвід харківських шкіл (за результатами відкритого конкурсу-захисту проектів) : Методичний посібник для заступників директорів ЗНЗ та вчителів, які працюють 3 обдарованими дітьми. Харків, 2009. 40 с.

3. Новий тлумачний словник української мови. Т. 4. К.: АКОНІТ, 1999. 684 с.

4. Гончаренко С. У. Український педагогічний словник. К.: Либідь, 1997. 376 с. 6.

5. Казакова Е. И. Сопровождение развития - новая образовательная технология // Писхолого-педагогическое, медико-социальное сопровождение развития ребенка / Е.И. Казакова. СПб., 2001. Ч.1. С. 9-14.

6. Рогальська I. Сутнісні характеристики соціально-педагогічного супроводу соціалізації особистості у дошкільному дитинстві. Гуманізація навчально-виховного процесу: збірник наукових праць. Слов’янськ: СДПУ, 2010. Ч. 1. С.230-236.

7. Байєр О. Психолого-педагогічний супровід розвитку дитини в освітньому процесі ДНЗ. Гуманізація навчально-виховного процесу: збірник наукових праць. Слов'янськ: СДПУ, 2010. Ч. 1. С. 21-31.

8. Педагогічний словник / За ред. М. Д. Ярмаченка. К.: Пед. думка, 2001. 514 с. - С.2.

9. Антонова О.Є. Психолого-педагогічний супровід обдарованої дитини як реалізація особистісно орієнтованого підходу // Професійно-педагогічна освіта: особистісно-орієнтований підхід : монографія / за ред. О.А. Дубасенюк. Житомир: Вид-во ЖДУ ім. Івана Франка, 2012. С. 316-345.

10. Казакова Е.И. Комплексное сопровождение развития учеников в образовательном процессе: аналитические материалы. СПб., 1998. 213 с. С. 78

11. Шакурова М.В. Педагогическое сопровождение становления и развития социокультурной идентичности школьников : дис. на соискание ученой степени д-ра пед. наук : спец. 13.00.01 / М.В. Шакурова. М., 2007. 361 с. С. 90

12. Иваненко М. Педагогическое сопровождение развития социального интеллекта ребенка в период детства: автореф. дисс. ... канд. пед. наук:13.00.07. Екатеринбург, 2005. $22 \mathrm{c}$.

13. Крутій К. Концептуальні засади психолого-педагогічного супроводу: принципи i техніки. Гуманізація навчально-виховного процесу: збірник наукових праць. Слов'янськ: СДПУ, 2010. Ч. 1. С. $185-198$.

14. Рогальська I. Сутнісні характеристики соціально-педагогічного супроводу соціалізації особистості у дошкільному дитинстві. Гуманізація навчально-виховного процесу: збірник наукових праць. Слов’янськ: СДПУ, 2010. Ч. 1. С.230-236.

15. Психолого-педагогічний супровід і підтримка в умовах модернізації освітньовиховного простору. http://osvita.ua/school/method/upbring/1334/

\section{References:}

1. Harvasiuk I. H. (2014). Psykholohichnyi suprovid obdarovanoi dytyny [Psychological support of a gifted child] // Osvita ta rozvytok obdarovanoi osobystosti. № 3 (22). S. 46-50. [in Ukrainian].

2. Siedova T. D. (2009) Tsinnisni oriientatsii pedahohichnoho suprovodu obdarovanykh uchniv osvitnomu seredovyshchi himnazii [Value orientations of pedagogical support of gifted students in the educational environment of the gymnasium] // Orhanizatsiia roboty $z$ obdarovanymy uchniamy: dosvid kharkivskykh shkil (za rezultatamy vidkrytoho konkursu-zakhystu proektiv) : Metodychnyi posibnyk dlia zastupnykiv dyrektoriv ZNZ ta vchyteliv, yaki pratsiuiut $z$ obdarovanymy ditmy. Kharkiv. 40 s. [in Ukrainian].

3. Novyi tlumachnyi slovnyk ukrainskoi movy [New explanatory dictionary of the Ukrainian language] (1999). T. 4. K.: AKONIT. 684 s. [in Ukrainian]. 
4. Honcharenko S. U. (1997). Ukrainskyi pedahohichnyi slovnyk [Ukrainian pedagogical dictionary]. K.: Lybid, 19. 376 s. 6. [in Ukrainian].

5. Kazakova E. Y. (2001) Soprovozhdenye razvytyia - novaia obrazovatelnaia tekhnolohyia [Development support - a new educational technology] // Pyskholoho-pedahohycheskoe, medykosotsyalnoe soprovozhdenye razvytyia rebenka / E.Y. Kazakova. SPb. Ch.1. S. 9-14. [In Russian]

6. Rohalska I. (2010). Sutnisni kharakterystyky sotsialno-pedahohichnoho suprovodu sotsializatsii osobystosti u doshkilnomu dytynstvi [Essential characteristics of socio-pedagogical support of socialization of the individual in preschool childhood]. Humanizatsiia navchalno-vykhovnoho protsesu: zbirnyk naukovykh prats. Sloviansk: SDPU. Ch. 1. S.230-236. [in Ukrainian].

7. Baiier O. (2010). Psykholoho-pedahohichnyi suprovid rozvytku dytyny v osvitnomu protsesi DNZ. [Psychological and pedagogical support of child development in the educational process of secondary schools] Humanizatsiia navchalno-vykhovnoho protsesu: zbirnyk naukovykh prats. Sloviansk: SDPU. Ch. 1. S. 21-31. [in Ukrainian].

8. Pedahohichnyi slovnyk [Pedagogical dictionary] (2001) / Za red. M. D. Yarmachenka. K.: Ped. dumka. 514 s. - S.2. [in Ukrainian].

9. Antonova O. (2012). Psykholoho-pedahohichnyi suprovid obdarovanoi dytyny yak realizatsiia osobystisno oriientovanoho pidkhodu [Psychological and pedagogical support of a gifted child as a realization of a personality-oriented approach] // Profesiino-pedahohichna osvita: osobystisno-oriientovanyi pidkhid : monohrafiia / za red. O.A. Dubaseniuk. Zhytomyr: Vyd-vo ZhDU im. Ivana Franka. S. 316-345. [in Ukrainian].

10.Kazakova E.Y. (1998). Kompleksnoe soprovozhdenye razvytyia uchenykov v obrazovatelnom protsesse: analytycheskye materyalы [Comprehensive support for the development of students in the educational process: analytical materials]. SPb. 213 s. S. 78 [In Russian]

11. Shakurova M.V. (2007). Pedahohycheskoe soprovozhdenye stanovlenyia y razvytyia sotsyokulturnoi ydentychnosty shkolnykov [Pedagogical support for the formation and development of the socio-cultural identity of schoolchildren] : dys. na soyskanye uchenoi stepeny d-ra ped. nauk: spets. 13.00.01 / M.V. Shakurova. M.. 361 s. S. 90 [In Russian]

12.Yvanenko M. (2005). Pedahohycheskoe soprovozhdenye razvytyia sotsyalnoho yntellekta rebenka $\mathrm{v}$ peryod detstva [Pedagogical support for the development of a child's social intelligence during childhood]: avtoref. dyss. ... kand. ped. nauk:13.00.07. Ekaterynburh. 22 s. [In Russian]

13. Krutii K. (2010). Kontseptualni zasady psykholoho-pedahohichnoho suprovodu: pryntsypy i tekhniky [Conceptual principles of psychological and pedagogical support: principles and techniques.]. Humanizatsiia navchalno-vykhovnoho protsesu: zbirnyk naukovykh prats. Sloviansk: SDPU. Ch. 1. S. 185 - 198. [in Ukrainian].

14.Rohalska I. (2010). Sutnisni kharakterystyky sotsialno-pedahohichnoho suprovodu sotsializatsii osobystosti u doshkilnomu dytynstvi [Essential characteristics of socio-pedagogical support of socialization of the individual in preschool childhood]. Humanizatsiia navchalno-vykhovnoho protsesu: zbirnyk naukovykh prats. Sloviansk: SDPU. Ch. 1. S.230-236. [in Ukrainian].

15. Psykholoho-pedahohichnyi suprovid i pidtrymka $\mathrm{v}$ umovakh modernizatsii osvitnovykhovnoho prostoru [Psychological and pedagogical support and support in the modernization of educational space]. http://osvita.ua/school/method/upbring/1334/ [in Ukrainian]. 